\title{
Sails: a new gypsum speleothem from Naica, Chihuahua, Mexico
}

\author{
Tullio Bernabei ${ }^{1}$, Paolo Forti ${ }^{2}$, Roberto Villasuso ${ }^{3}$
}

\begin{abstract}
:
Bernabei T., Forti P. 2007. Sails: a new gypsum speleothem from Naica, Chihuahua, Mexico. International Journal of Speleology, 36 (1), 23-30 Bologna (Italy). ISSN 0392-6672.

The caves of Naica (Chihuahua, Mexico) are perhaps the most famous mine caves of the world due to the presence of gigantic gypsum crystals. Nevertheless, very little research has been carried out on this karst area until now. A multidisciplinary investigation started in 2006 with the aim not only to define the genesis and the age of the Naica gypsum crystals, but also on other scientific aspects of these caves.

This paper describes a completely new type of gypsum speleothem: the "sails", observed only inside the Cueva de las Velas, one of the caves of the Naica system. This speleothem consists of extremely thin, elongated skeleton crystals that have grown epitaxially only on the tips of the gypsum crystals pointing upward. The genesis of sails is strictly related to the environmental conditions set up inside the cave just after the artificial lowering of the groundwater by mine dewatering (less than 20 yr ago). In a few years sail speleothems will disappear entirely and therefore this study is fundamental to preserve at least the memory of them.
\end{abstract}

Keywords: gypsum speleothems, speleogenesis, mine caves, Naica, Mexico

Received 15 September 2006; Revised 6 November 2006; Accepted 7 November 2006

\section{INTRODUCTION}

The systematic study of "mine caves" has emphasized the high scientific interest of the minerogenetic processes active therein and consequently of the crystals that they sometimes host (Forti, 2005; De Waele and Naseddu, 2005).

From this point of view, the natural cavities crossed by mine galleries in Naica (Chihuahua, Mexico) (Fig. 1) have been world renowned for over a century, due to the dimension and purity of their gypsum crystals (Hill \& Forti, 1997). Besides Cueva de las Espadas (Cave of the Swords), unveiled at the beginning of the $20^{\text {th }}$ century at the -120 level, where crystals up to 2 meters in length exist (Degoutin, 1912; Foshag, 1927; Johnson P.W., 1963; Rickwood, 1981; Sabagun \& Winchell, 2001), in the last 5-6 years mine galleries at the -290 level have intercepted several natural cavities, the most important of which are Cueva de los Cristales (Crystal Cave), Ojo de la Reina (Queen's Cave) and Cueva de las Velas (Sails Cave) (Fig. 1). All these caves host gypsum crystals much bigger than those in the Cave of the Swords. The largest of these crystals, which are over $13 \mathrm{~m}$ in length, have been found in Crystal Cave (Fig. 2) (London, 2003). Even if these crystals are by far the largest gypsum crystals in

\footnotetext{
${ }^{1}$ La Venta Exploring team, Via Priamo Tron 35/F, 31100 Treviso (Italy) (tux@tulliobernabei.it)

${ }^{2}$ Istituto Italiano di Speleologia \& La Venta Exploring Team, University of Bologna, Via Zamboni 67, 40126 Bologna, Italy (forti@geomin.unibo.it)

${ }^{3}$ Compañia Fresnillo, Unitad Naica, Mexico
}

the world the scientific importance of the caves is not confined to this aspect. There are many other features also worthy of study.

One of the strangest things occurring in these caves are several extremely thin and elongated gypsum crystals, which have been observed only in Cueva de las Velas. The first explorers called these crystals velas (sails) due to their particular shape (Fig. 3). The study of these strange crystals is a part of a general research project which the owner of the mine, the Peñoles Company, decided to commit to La Venta Exploring Team from Italy and Speleoresearch \& Films of Mexico City in 2006 (Forti, 2006).

In the present paper, after a short geologic outline of the Naica area, the genetic mechanism responsible for the development of these new gypsum speleothems is discussed in detail. The sails evolution was strictly related and controlled by the peculiar environmental conditions established in the Cueva de las Velas due to the workings within the mine.

\section{GEOLOGICAL SETTING}

Naica mine is located in a semi-desert region some $100 \mathrm{~km}$ southeast of Chihuahua, the capital town of the homonymous Mexican State bordering on USA (Fig. 1). The mine opens at $1385 \mathrm{~m}$ a.s.1. in the northern flank of the Sierra de Naica, a $12 \mathrm{~km}$ long, $7 \mathrm{~km}$ wide, anticline structure of carbonate formations oriented northwest-southeast. This antiform outcrops from a very extensive alluvial plain. At the regional scale the Naica carbonate sequence consists of limestone, 


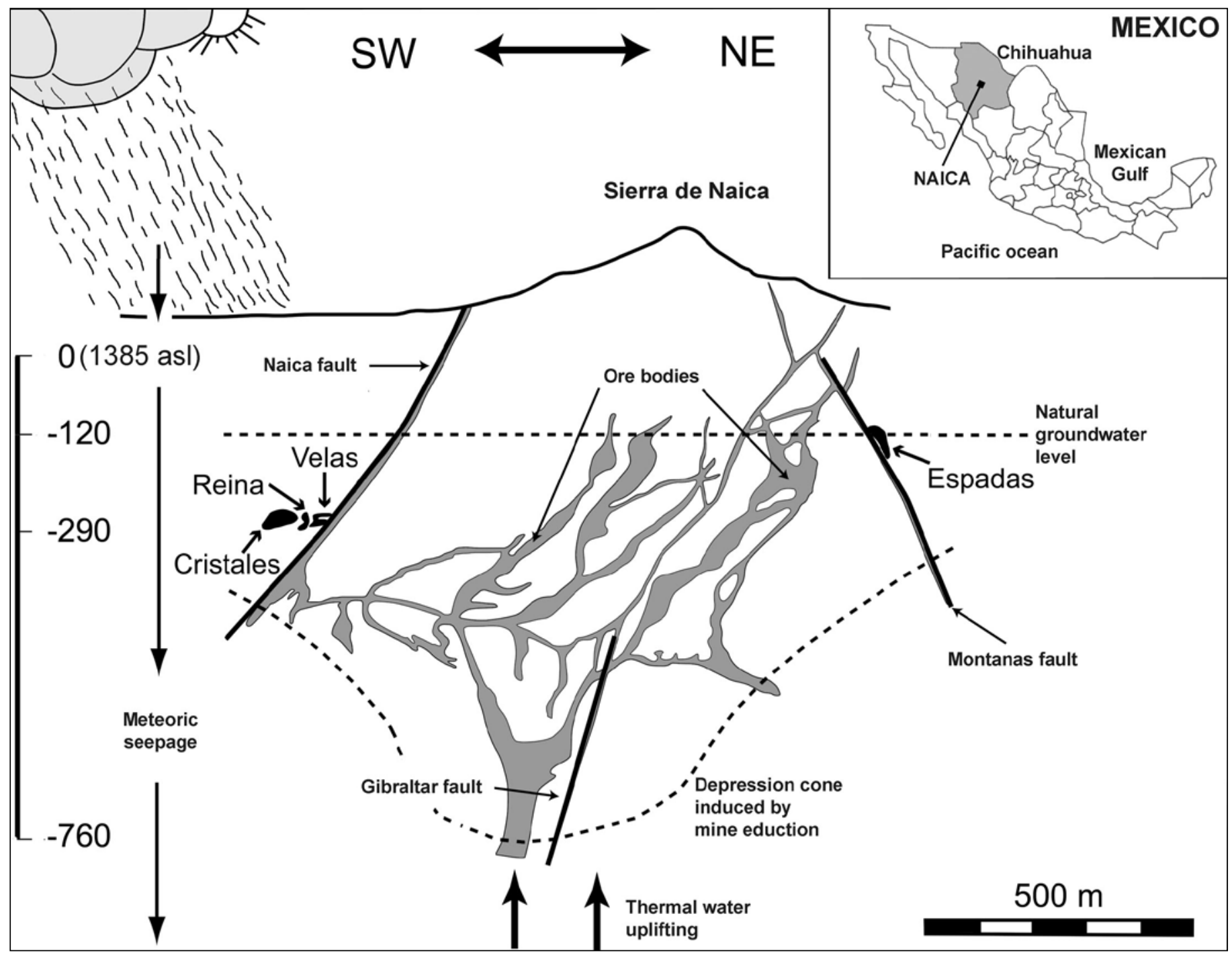

Fig. 1. Sketch of the mine in which the main natural cavities are related to the original groundwater level.

dolomitic limestone and calcitic dolostone with lutitic interbeds overlying an Aptian evaporitic sequence. The carbonate sequence started its deposition during Albian time (Cretaceous) and its sedimentation went on for several tens of millions of years (Palacios et al., 1991). In the mine location the whole ore body is within the carbonate sequence and up to now no trace of the Aptian evaporites has been found within cores drilled up to over $1 \mathrm{~km}$ in depth.

Tertiary intrusive magmatic activity, which characterized this part of the North American subcontinent, caused the development of acid dikes, some 26.2-25.9 Myr BP within the carbonate sequence (Megaw et al., 1988). Recent magnetometric studies have unveiled an igneous source at a depth of between 2.5 and $5 \mathrm{~km}$ some $4 \mathrm{~km}$ south of Naica. The polysulphide $(\mathrm{Pb}, \mathrm{Zn}, \mathrm{Ag})$ ore bodies are related to hydrothermal flows (Erwood et al., 1979) induced by the Tertiary dykes. The mineral deposit (consisting mainly of pyrite, pirrotine, sphalerite, galena and chalcopyrite) displays chimney and manto shapes developed within dikes and hosting carbonate formations. The latter are consequently strongly altered and partially transformed into calcosilicates (Lang, 1995). During a later stage, when the thermal fluids got colder, calcite, anhydrite and quartz formed veins within the ore bodies (Stone,

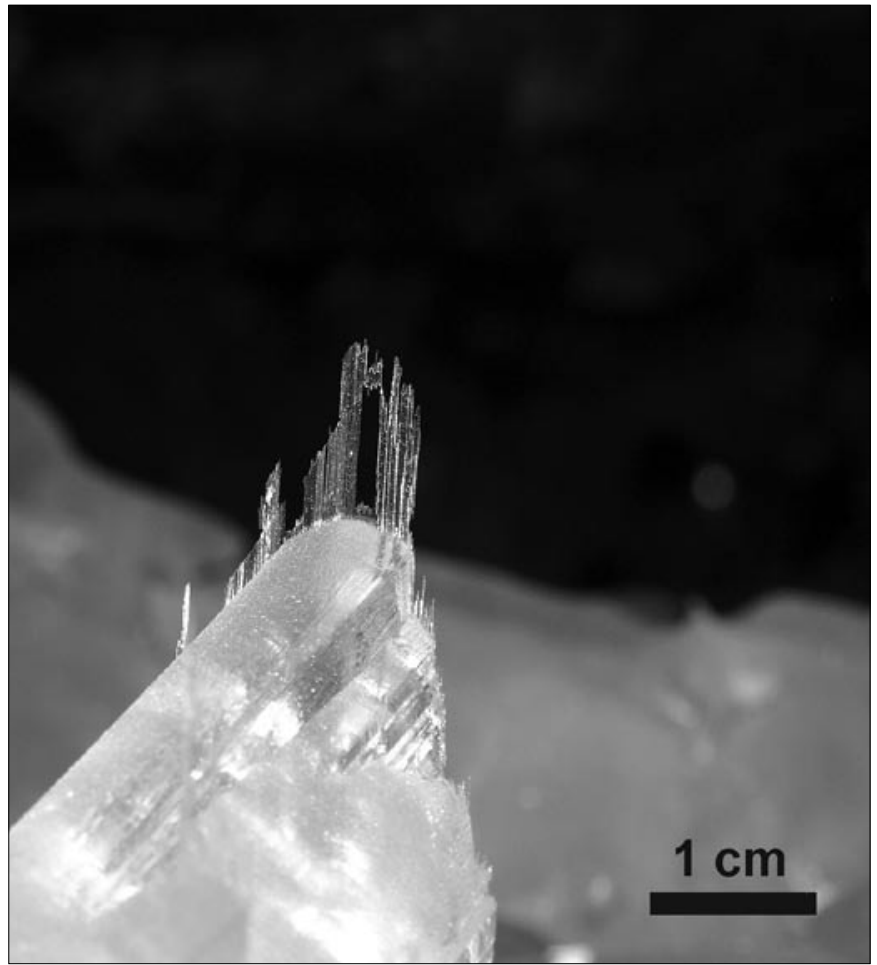

Fig. 3. A "sail" growing epitaxially over a pre-existing large gypsum crystal with its apex pointing upward (photo by Tullio Bernabei, Archivio La Venta \& S/F). 


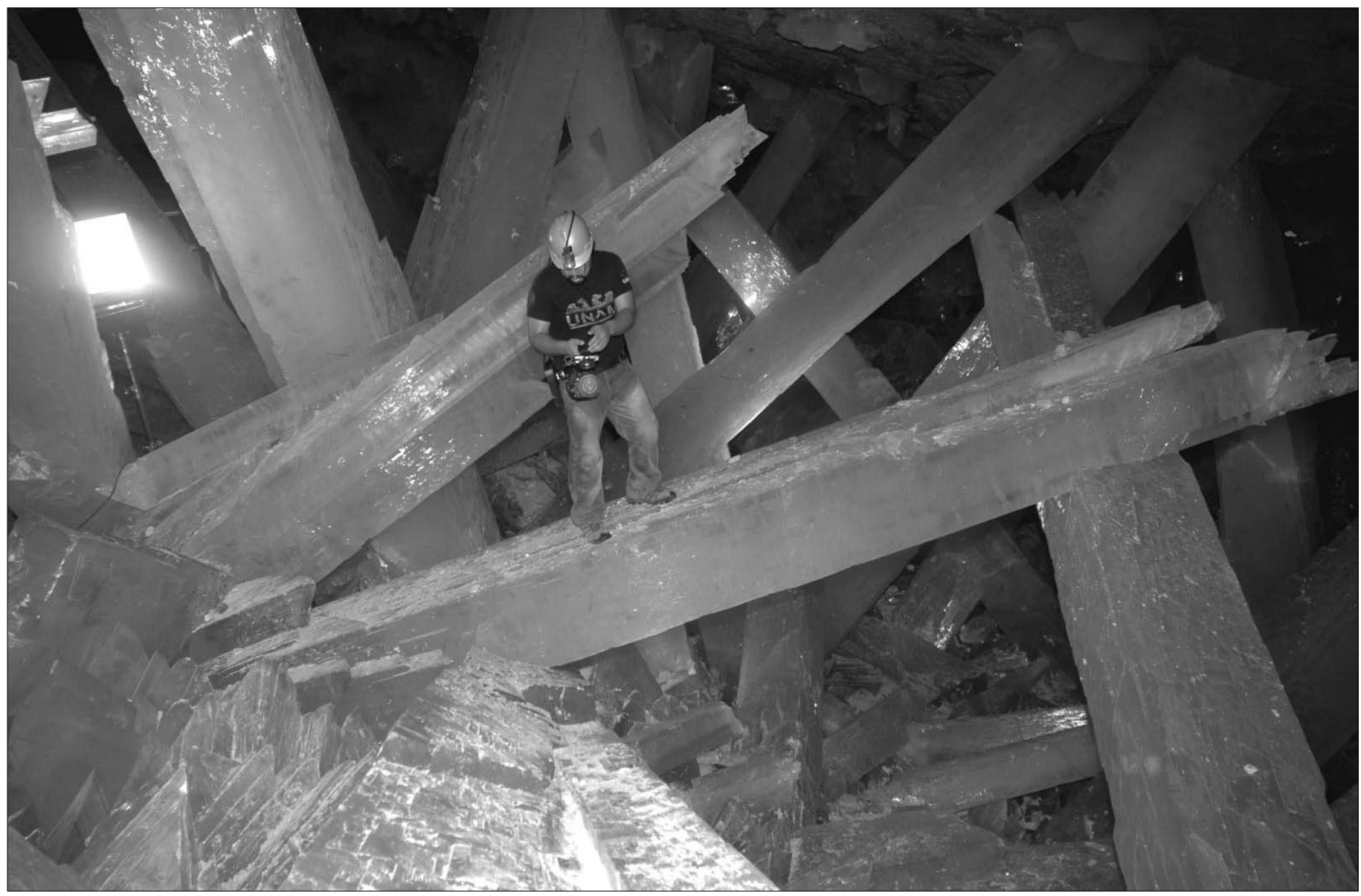

Fig. 2. Cueva de los Cristales: the largest gypsum crystals of Naica (photo by Giovanni Badino, Archivio La Venta \& S/F).

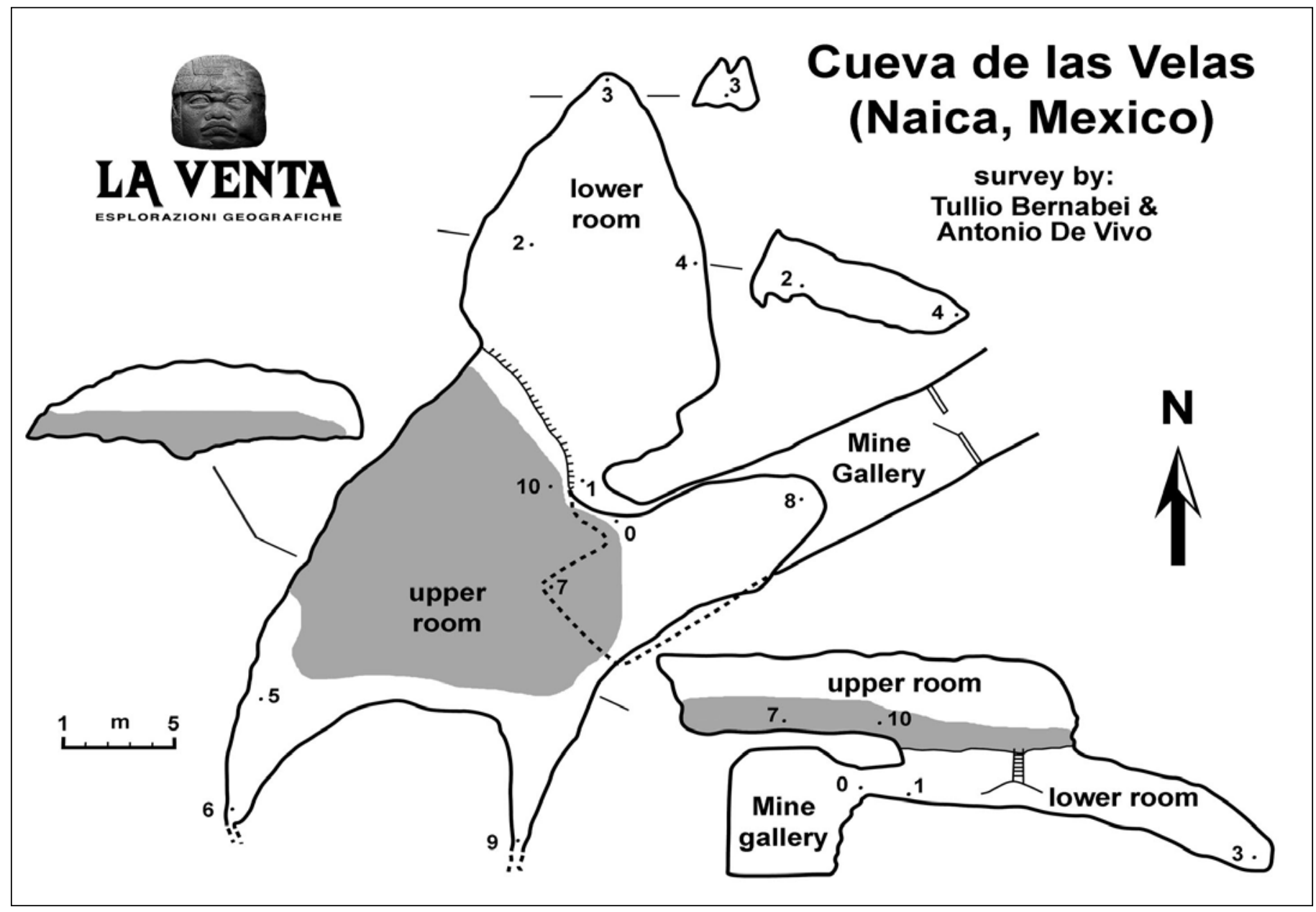

Fig. 4. Plan and vertical sections of the Cueva de las Velas: the grey area is where the sails have developed. 


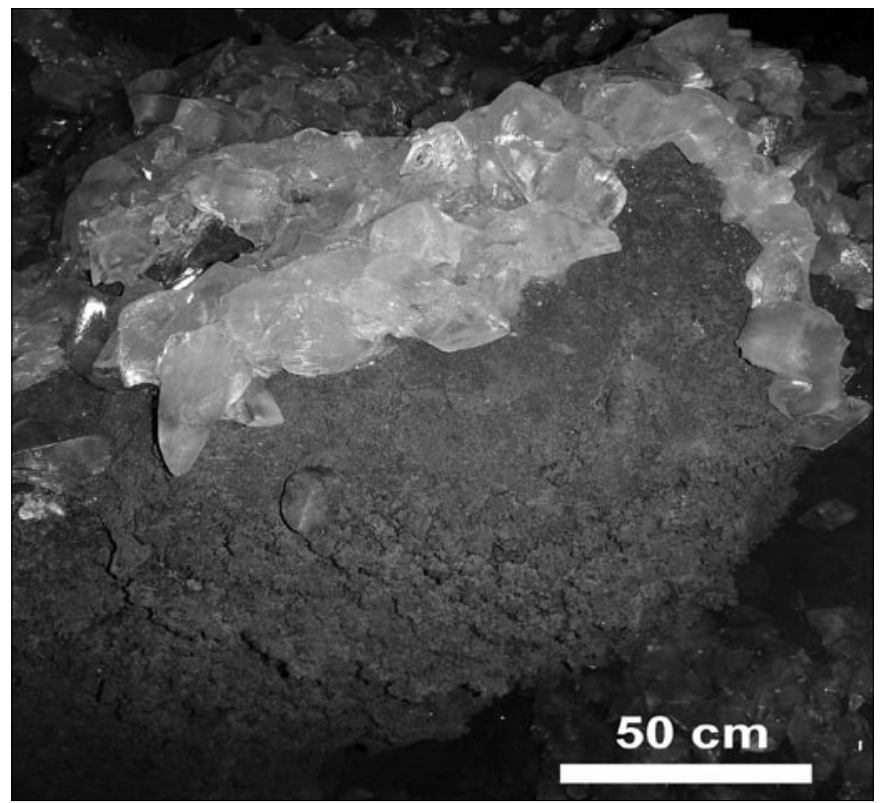

Fig. 5. A portion of the cave wall in which a thick deposit of metallic oxides-hydroxides are exposed (photo by Tullio Bernabei, Archivio La Venta \& S/F).

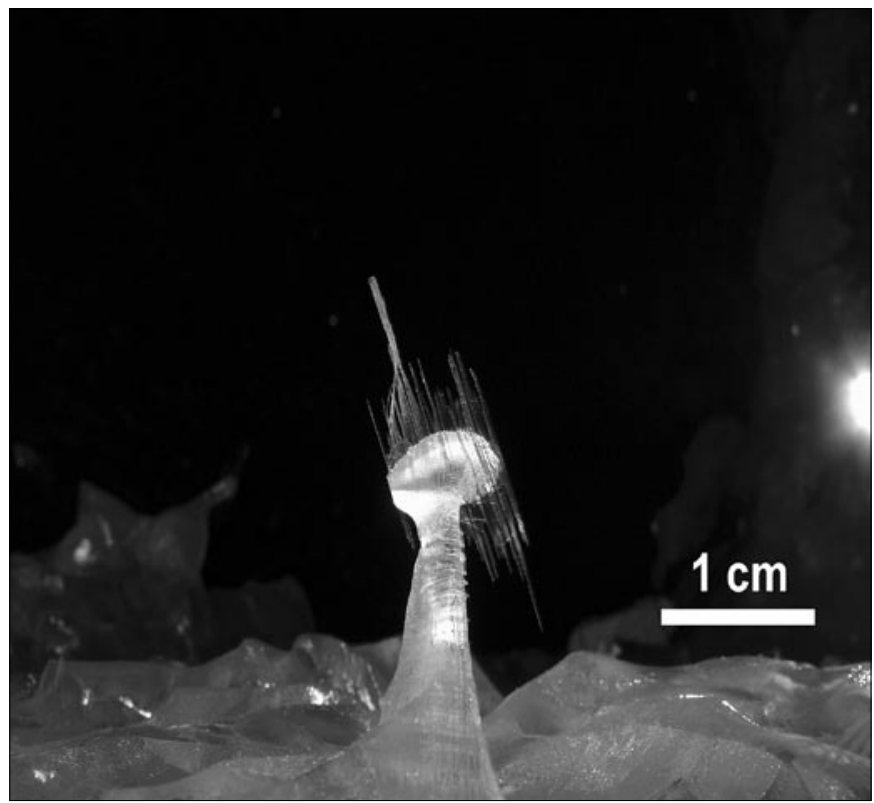

Fig. 6 A "sail" developing over a re-dissolved gypsum crystal with the characteristic stalk shape (photo by Tullio Bernabei, Archivio La Venta \& $S / F)$.

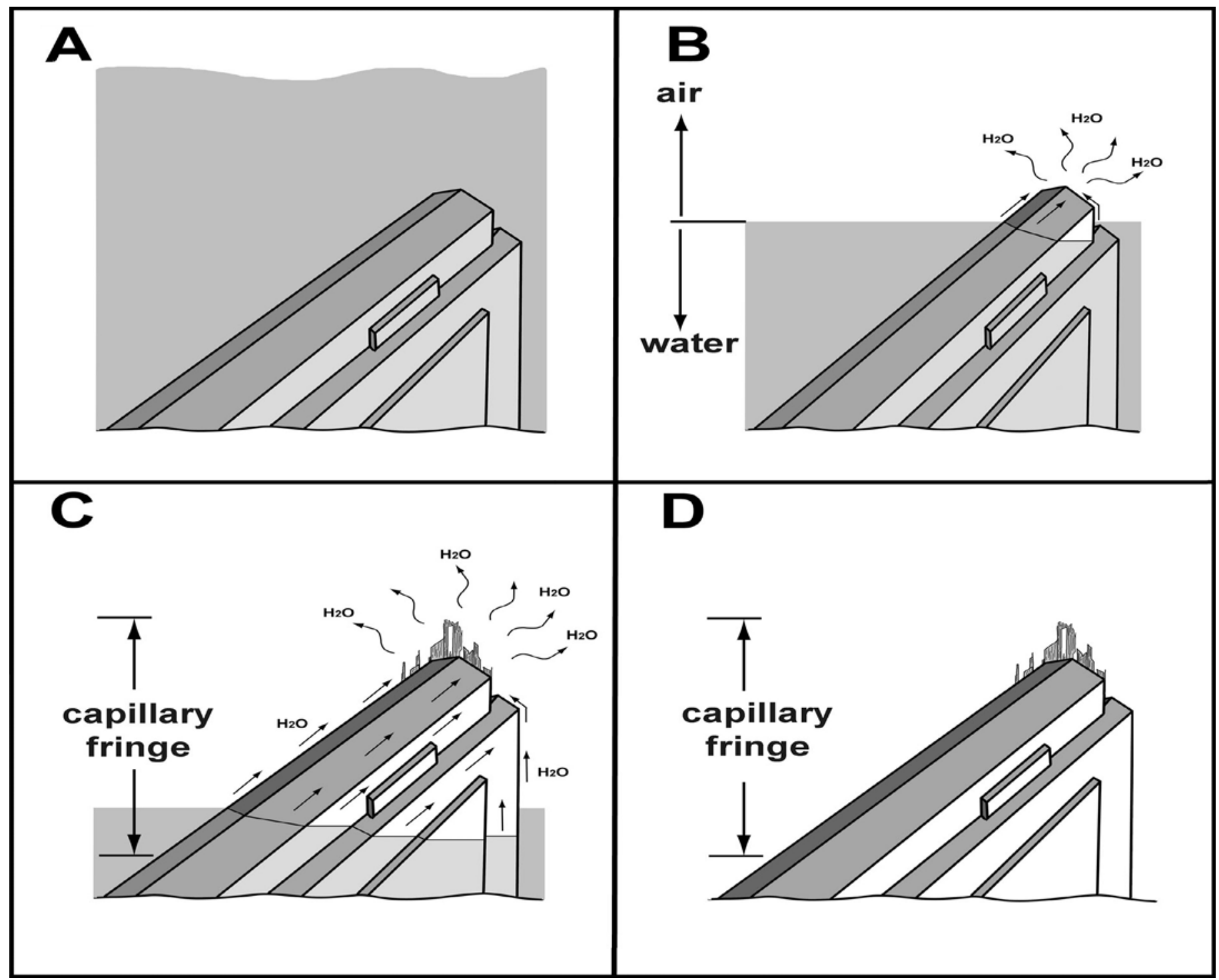

Fig. 7. Main genetic steps for sails: A- the growth of macrocrystals continued as long as the crystals were completely submerged; B- when the artificial lowering of groundwater during mine development caused crystals to be exposed to atmospheric capillary uplifting and evaporation started; C- Supersaturation at the crystal apex induced the deposition of gypsum and a "sail" developed, with its characteristic shape being controlled by strong upward air; D- the process ended when the distance between the crystal apex and the water surface exceeded the capillary fringe. 
1959).

Two different fault sets were the main structural controls for hydrothermal circulation and therefore for the location of the mineral deposits. The most important of them are the Gibraltar, Naica and Montaña faults (Fig. 1). These structures still control the thermal water flow within the Naica anticline: almost all the water springing in the deep mine galleries comes from fractures related to these faults. Their important role in water circulation is also confirmed by the fact that all the main caves are strictly related to them (Fig. 1). Mine activities have reached -760 below the mine entrance (level 0 at $1385 \mathrm{~m}$ a.s.1.), and they are some 630 $\mathrm{m}$ below the original groundwater level which was at $-130(1255 \mathrm{~m}$ a.s.1.): presently to maintain the mine galleries dry a dewatering of about $1 \mathrm{~m}^{3} / \mathrm{s}$ is required.

The whole Naica area is still under a thermal anomaly. Water springing in the mine galleries has a temperature close to $53^{\circ} \mathrm{C}$. A recent study (Mine of Naica unprinted report, 2006) has demonstrated the meteoric origin of these waters, even if the average residence time within the thermal aquifer is rather long (over 50 years).

\section{EXPERIMENTAL OBSERVATIONS}

The Cueva de las Velas is the latest large mine cave found at Naica. This cavity was intercepted in 2005 very close to the Naica fault and in April 2006 it was explored and mapped by Tullio Bernabei and Antonio De Vivo of the La Venta Exploring Team. The entrance (about $1.5 \times 1 \mathrm{~m}$ ), which lets cavers into the lower part of the cavity, is close to the gallery ceiling and requires a $4 \mathrm{~m}$ climbing to be reached. The cave, which has a total length of about $80 \mathrm{~m}$, is oriented north-south and consists of two main large rooms partially superimposed (Fig. 4). The average height of the chambers is $3-4 \mathrm{~m}$, while their width often is over 10 $\mathrm{m}$. In order to reach the upper room from the lower one a $3 \mathrm{~m}$ climb is required.

The morphology of the few parts

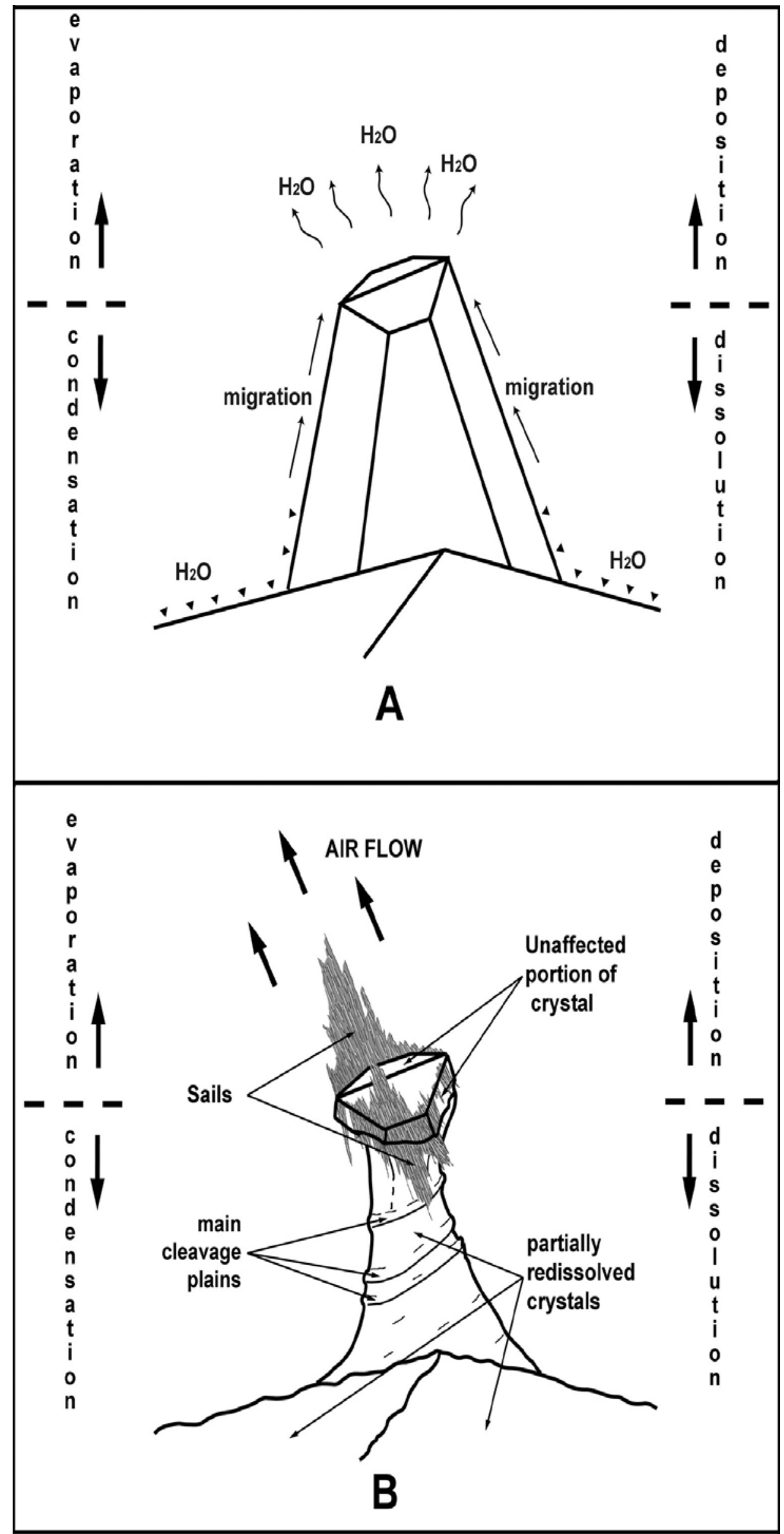

Fig. 8. The evolution of a sail over a partially re-dissolved gypsum crystal: A- initial stage: condensation over the macrocrystals induced capillary uplifting and evaporation from the crystal apex; B- final stage: the sail shape was controlled by air current within the cave, while the "stalk" was the consequence of capillary uplifting of unsaturated water. 
of the cave free of gypsum crystals shows that karst evolution was mainly controlled by bedding planes, while, at least in one developing stage before the deposition of gypsum, acid aggression induced by sulphide oxidation was the main corrosion factor. Actually the Cueva de las Velas has a temperature of about $43-45^{\circ} \mathrm{C}$ which is intermediate between those of Cueva de los Cristales and Ojo de la Reina, while its relative humidity (less than $80 \%$ ) is the lowest one.

Presently Cueva de las Velas is the single cavity of Naica in which most of the carbonate rock, whether covered or not by gypsum crystals, is overlain by a thick (up to 20-50 cm) deposit of metallic (mainly $\mathrm{Fe}$ and $\mathrm{Mn}$, with minor $\mathrm{Pb}$ and traces of $\mathrm{Zn}$ ) oxideshydroxides (Fig. 5). These deposits, which are now object of a detailed study (Forti et al., 2006), are much more frequent and thick in the lower room, which therefore exhibits a much darker aspect. Another thing that is peculiar to this cave with respect to all the other cavities at the -290 level is that the surface of its gypsum crystals is partially re-dissolved, thus giving them a pearly lustre, whitish aspect while crystals in the other caves are absolutely transparent. But what makes Cueva de la Velas absolutely special is the presence of many small, thin and very delicate speleothems (the sails), developed on top of the gypsum crystals in the upper room of the cave.

The sail speleothems resemble formations made by fibrous gypsum, but in reality the sails consist of skeletal, strongly elongated crystals, reaching a total length of a few tens of millimetres, while their thickness never exceeds $1 \mathrm{~mm}$. The skeleton crystals have evidently grown epitaxially over the gypsum of the floor and walls of the chamber but only over the gypsum crystals whose apex is directed upwards (Fig. 3). The surface of a crystal, over which a sail has developed, is often so strongly dissolved as to give rise to a characteristic "stalk" under the overhanging apex, which stalk is not dissolved, and over which epitaxial growth of the skeleton crystal has occurred (Fig. 6).

\section{DISCUSSION}

The experimental observations carried out within the cave have determined the genetic mechanism responsible for the evolution of these new and particular speleothems. The presence of widespread dissolution features over the large crystals and the few and well defined places of development for sails are evidence of an undersaturated environment with respect to gypsum, but with the exception of those apexes pointing upward on which the sails are located. Clearly, such boundary conditions do not fit with the present day ones. In fact inside the cave no active condensation/evaporation processes at all have been observed during any of our visits: sails and the other gypsum crystals were constantly completely dry. This because the geothermal flow within this cave induces an extremely low difference in temperature between cave walls and its atmosphere (far less than $1{ }^{\circ} \mathrm{C}$ ), which is not enough to reach the dew point (Dublyansky \& Dublyansky, 1998). But these boundary conditions cannot have become established inside a cave deep inside the thermal aquifer. Under saturated conditions the single active process was, and still should be (Naica Mine unprinted report) the slow accretion of large gypsum crystals (Fig. 7A). Moreover, the noticeable upward directionality of the sails suggests the presence of a gentle uplifting air flow ruling the evolution of these speleothems. In fact, sails may be regarded as a sub-type of rims (Hill $\&$ Forti, 1997). Finally the development of skeleton crystals instead of euhedral ones is an indirect proof that the speed of growth by far exceeded the rather modest supply of material by capillarity.

These boundary conditions perfectly fit with an aerate environment where evaporation processes are active, thus inducing an upward air current controlled by convective motion of moist air (Fig. 7B). However, such a process will shortly induce localized supersaturation with respect to gypsum just where the evaporation occurs (Fig. 7C). This also explains why the sails have developed only over the crystal apexes pointing upward: the capillary uplifting is controlled by evaporation which occurs mainly on the highest places (i.e. the crystal tips).

But evaporation requires the presence of a gas phase, and therefore the development of sails had to start only when mine pumping lowered the groundwater level below that of the cave (that is, more than about $160 \mathrm{~m}$ below the natural level), which event occurred some 20 years ago. Progressive dewatering of the cave at first allowed only the top of the crystals to crop out from the thermal water but later, probably in a few months or even less, the entire cavity dried up.

On the basis of this genetic mechanism it can be reliably stated that the period in which the sails developed was very short. The progressive cave dewatering brought the air-water interface to a level where the distance from the top of the crystals and the water surface was greater than the capillary fringe (Fig. 7D). When that happened, the feeding process induced by the uplift controlled by evaporation stopped. However, the stop in the sail evolution did not necessarily correspond to this event. For a short period of time after the complete dewatering of the cave, sails were fed by condensation water. This process started when the walls of the dewatered cavity began to cool due to the lacking of a direct contact with the thermal water, and also due to the presence of a cooler air circulation coming from the mine galleries. In this way the walls reached a temperature lower than that of the still uplifting moist air, the temperature of which, deriving from that of the thermal water, was rather constant over time. Therefore, when the gypsum crystals reached the dew point, water started to condensate over them thus inducing widespread dissolution over the crystal surfaces. The high efficiency of this process together with the relative small amount of re-dissolved gypsum are indirect proofs of the very short period of time that the condensation process lasted.

Where the capillary uplift was particularly high, the gypsum crystals underwent a higher dissolution. 
The intensity of such a process changed from point to point over the crystal faces, being normally stronger at the bottom (Fig. 8A), where undersaturation was the highest. The dissolution process increased the content in $\mathrm{Ca}^{2+}$ and $\mathrm{SO}_{4}{ }^{=}$of the uplifting water and therefore its undersaturation progressively decreased so that, normally, close to the crystal apex the saturation toward gypsum avoided any kind of dissolution of this part. At the apex evaporation induced a slight supersaturation thus allowing the epitaxial development of the sail on top of the crystal (Fig. 8B). Further lowering of the groundwater (now several hundred metres below the cave), with the consequent cooling down of the uplifting vapours, together with the termination in a decrease of temperature within the Cueva de las Velas, rapidly avoided condensation and therefore the evolution of the sails ended.

But a question still needs to be answered: why, did sails not develop in any other cave at the -290 level, despite the closeness of these caves to each other? First, it must be noticed that the surfaces of the gypsum crystals in the other 2 caves (Cristales and Reina) show no dissolution features at all. This fact is evidence that climatic conditions inside these cavities never allowed for condensation processes to occur ( i.e. the dew point was never reached). No condensation means no capillary uplifting and no evaporation: therefore no sails developed as a result of this mechanism. However, as for Cueva de las Velas, sails would have had the possibility to develop in Cueva de los Cristales and Ojo de la Reina due to the capillary fringe process during the first stages of cave dewatering, so the total absence of sails must be interpreted as indirect proof of a very fast dewatering of these two cavities if compared to that of Cueva de las Velas.

Even marked differences in the cave hydrodynamics are reasonable and easily justifiable. The connection with the thermal aquifer may tremendously vary from cave to cave depending on their relative distance from the Naica fault, which is one of the main water uplifting ducts. Moreover, the local water flow may have been more or less affected by the evolution of the giant gypsum crystals in that the formation of these crystals in the Naica caves can be directly linked to faults, which caused the aquifer to have become partially or totally sealed. This hypothesis is compatible with the present day differences in air temperature and relative humidity measured within the three Naica caves, because these parameters are, at least partially, directly linked with the amount of vapours reaching the caves from the deep aquifer.

Finally it is reasonable to suppose that a rather important role in sail development was played by the thick metallic oxide-hydroxides layer, which underlie the gypsum crystals exclusively in the Cueva de las Velas. These sediments are able to adsorb a large amount of water, which may be slowly released to feed the capillary uplifting over the gypsum crystals. Moreover the water coming from these sediments has surely a small (if any) content of $\mathrm{CaSO}_{4}$ thus allowing for the partial dissolution of the crystals.

\section{FINAL REMARKS}

The exploration of the Cueva de las Velas within the Naica mine has allowed the study of a new type of gypsum crystal, which represents the latest stage in the development of the cavity. The sails grew over a short span of time, only some 20 years or so, just after the artificial lowering of the groundwater level induced by mine dewatering. From a reconstruction of the environmental conditions within the cave at the time of sail development, it can be reasonably proposed that the planar direction structure of such speleothems is controlled by an equilibrium between capillary uplifting along the gypsum crystal faces, the evaporation occurring on their upward pointing apexes, condensation and partial dissolution. The criticality of these equilibrium mechanisms is evident because, at least presently, the Cueva de las Velas is the single cave, not only within the Naica mine but in the entire world, in which these peculiar speleothems have had the unique possibility to develop.

Unfortunately these strange crystals, as for all of the other karst phenomena at the -290 level of Naica mine will remain visible only for a few years, and as soon as the mining activities stop (an event that is expected within 5 years), the uplifting of groundwater will submerge them under some $170 \mathrm{~m}$ of water. In reality, the sails run the risk of destruction even earlier due to condensation processes. The walls of this cave, as those of all the other cavities of the -290 level, undergo a rather fast cooling due to the forced ventilation of the mine galleries. This process may bring in a short time the cave walls to have a temperature low enough, with respect to that of the uplifting vapours, so that the dew point will be reached and surpassed (De Freitas \& Schmekal, 2003; FernandezCortés et al., 2006a, b). When that happens, strong condensation will occur with the consequence of a fast complete dissolution of the sails and, subsequently, even the complete destruction of the giant gypsum crystals. This process has already started within the smallest cave at the -290 level (Ojo de la Reina), where the large gypsum crystals are presently intensively dissolved.

\section{ACKNOWLEDGEMENTS}

This research has been performed in the framework of the "Naica Project" conducted by Speleoresearch \& Films of Mexico City in co-operation with La Venta Exploring Team of Italy.

The Authors thanks Peñoles Company for allowing the access inside the Naica Mine and for their help given during the field work, José Maria Calaforra, Carol Hill and Charles Self for useful discussion and revision of the manuscript.

\section{REFERENCES}

De Freitas C.R. \& Schmekal A., 2003 - Condensation as a microclimate process: Measurements, numerical simulation and prediction in Glowworm Cave, New Zealand. International Journal of Climatology, 23(5): 557-575. 
De Waele J. \& Naseddu A. (Ed.), 2005 - Le grotte di miniera tra economia mineraria ed economia turistica, Memorie dell'Istituto Italiano di Speleologia, serie II, 17, 198 p.

Degoutin N., 1912 - Les grottes a cristaux de gypse de Naica. Soc. Cient. Antonio alzate Rev., 32: 35-38.

Dublyansky V.N. \& Dublyansky Y.V., 1998 - The problem of condensation in karst studies. Journal of Cave \& Karst Studies, 60(1): 3-17.

Erwood R.J., Kesler S.E. \& Cloke, P.L., 1979 Compositionally distinct, saline hydrothermal solutions, Naica Mine, Chihuahua, Mexico. Economic Geology, 74: 95-108.

Fernández-Cortés A., Calaforra J.M. \& Garcia-Guinea J., 2006a - The Pulpi gigantic geode (Almeria, Spain): geology, metal pollution, microclimatology and conservation. Environmental Geology, 50: 707-716.

Fernández-Cortés A., Calaforra J.M., Sánchez-Martos F. \& Gisbert J., 2006b - Microclimate processes characterization of the giant geode of Pulpi (Almeria, Spain): technical criteria for conservation. International Journal of Climatology, 26: 691-706.

Forti P., 2005 - L'importanza scientifica delle grotte di miniera. Memorie dell'Istituto Italiano di Speleologia, serie II, 17: 15-22.

Forti P., 2006 - Le grotte di Naica e i loro giganteschi cristalli di gesso. Geoitalia (in press).

Forti P., Galli E. \& Rossi A., 2006 - Mineralogy of Cueva de las Velas (Naica, Chihuahua, Mexico). Acta Carsologica submitted).

Foshag W., 1927 - The selenite caves of Naica, Mexico. American Mineralogist, 12: 252-232.
Hill C.A. \& Forti P., 1997 - Cave minerals of the World. National Speleological Society, Huntsville, 464 p.

Johnson P.W., 1963 - Naica and its Cave of the Swords. Mineralogist, 31(3): 4-10.

Lang J.R., 1995 - A geological evaluation of the Naica deposit, Chihuahua, Mexico. Internal Report of Compañia Fresnillo, 109 p.

London D., 2003 - New "Cave of the Crystals" at Naica, Chihuahua, Mexico. Earth Scientist Magazine: 24-27.

Megaw P.K.M., Ruiz J. \& Titley S.R, 1988 - Hightemperature, carbonate-hosted $\mathrm{Pb}-\mathrm{Zn}$ - $\mathrm{Ag} \quad(\mathrm{Cu})$ deposits of northern Mexico. Economic Geology, 83: $1856-1885$.

Palacios M.H.A., Querol F.S. \& Lowther G.K., 2001 Geology and genesis of the Naica mineral deposits, Chihuahua. In: Salas G.P. (Editor). Economic Geology, Mexico. Geological Society of America, Boulder (Co): 259-265.

Rickwood P.C., 1981 - The largest crystals. American Mineralogist, 66: 885-908

Sabagun C.L., Winchell J.R., 2001 - Naica's glittering new crystal cave, Chihuahua, Mexico. Rocks and Minerals, 76(5): 347-349.

Stone J.G., 1959 - Ore genesis in the Naica District, Chihuahua, Mexico. Economic Geology, 54: 1002-1034.

Forti P., 2006 - Le grotte di Naica e i loro giganteschi cristalli di gesso. Geoitalia, 18: 29-34 